\title{
Effect of Ramadan Fasting on Red and White Blood Cell Parameters in Healthy Females
}

\author{
Ramazan Orucunun Sağııklı Kadınlarda Kırmızı ve Beyaz Kan Hücresi Parametrelerine Etkisi
}

\section{Osamah Awad Ahmed}

Department of Fundamental, College of Nursing, Raprin University Ranya, Iraq

\section{ABSTRACT}

Objective: The point of present review is investigation of Red Blood Cell Parameters and white Blood Cell Parameters among fasted females during Ramadan month.

Methods: Thirty female subjects participated in current study. Estimation Red Blood Cell Parameters, Total and differential leucocytes counts were before 3 days and 28th day of the Ramadan month that Estimation was using fully automatic hematological analyzer.

Results: Hemoglobin, Hematocrit, Mean corpuscular volume (MCV), Mean corpuscular hemoglobin concentration (MCHC), Mean corpuscular hemoglobin concentration (MCHC), Red Cell Density Width -coefficient of variation (RDWCV), Red Cell Density Width -standard deviation (RDW-SD),Lymphocytes percent and Neutrophils percent were significantly increased during the Ramadan fasting period as compared to pre-Ramadan fasting period. White blood cells (WBC) count decreased significantly in end of the Ramadan month as compared to pre-Ramadan fasting.

Conclusions: This study shows in females' student graduate that fasting in the Ramadan month had effect on red blood cell indices and Total and differential leukocytes counts except RBC count and MXD.

Key Words: Ramadan Fasting, total white blood count, differential leukocytes counts, erythrocyte's parameters

Received: 03.19 .2017
Accepted:02.21.2018

\section{ÖZET}

Amaç: Bu çalışmanın amacı, Ramazan ayı boyunca oruç tutan kadınlarda kırmızı kan hücresi parametreleri ve beyaz kan hücresi parametrelerinin araştırılmasıdır. Yöntem: Çalışmaya 30 sağlıklı kadın katılmıştır. Kırmızı Kan Hücresi Parametreleri, lökosit sayıları, Ramazan ayından 3 gün önce ve 28'inci günlerinde tam otomatik hematolojik analiz cihazı kullanılarak yapılmıştır.

Bulgular: Hemoglobin, Hematokrit, Ortalama korpusküler hacim (MCV), Ortalama korpusküler hemoglobin konsantrasyonu (MCHC), Ortalama korpusküler hemoglobin konsantrasyonu (MCHC), Kırmızı Hücre Yoğunluk Genişliği-varyasyon katsayısı (RDW-CV), Kırmızı Hücre Yoğunluk Genişliğistandart sapma (RDW-SD) değerleri, Lenfosit yüzdesi ve Nötrofil yüzdesi Ramazan öncesine göre oruç döneminde, anlamlı olarak arttı. Beyaz kan hücrelerinin (WBC) sayısı ise Ramazan öncesine göre anlamlı şekilde azaldı.

Sonuç: Bu çalışmada, Ramazan ayında oruç tutmanın kırmızı kan hücresi indeksleri üzerinde etkili olduğunu ve RBC sayısı ve MXD hariç Toplam ve diferansiyel lökosit sayımları üzerine etkisini göstermektedir.

Anahtar Sözcükler: Ramazan orucu, toplam beyaz kan sayımı, diferansiyel lökosit sayımı, eritrosit parametreleri

Geliş Tarihi: 19.03.2017

Kabul Tarihi:21.02.2018

\footnotetext{
Address for Correspondence / Yazışma Adresi: Osamah Awad Ahmed, Department of Fundamental, College of Nursing, Raparin University, Ranya, Iraq E-mail: mahdi_qusay@yahoo.com

CTelif Hakkı 2019 Gazi Üniversitesi Tıp Fakültesi - Makale metnine http://medicaljournal.gazi.edu.tr/ web adresinden ulaşılabilir.

CCopyright 2019 by Gazi University Medical Faculty - Available on-line at web site http://medicaljournal.gazi.edu.tr/

doi:http://dx.doi.org/10.12996/gmj.2019.01
} 


\section{INTRODUCTION}

Ramadan fasting is a sacrament in Muslims people. Hundreds of millions of the Muslims should fast every day in Ramadan month under difference conditions. The hours of fasting in Ramadan month shift from 10-17 hours due to it depend on nature, Places, also seasons. During the month of Ramadan, The Muslims must abstain food, water, intercourse, oral remedy, fluids and supplements in daylight hours and eat two a guideline dinner after sunset. There are alterations in quality and quantity of eating, drink, daily work, scheduling of meals and rest cycle during the month of Ramadan (1). The amount of fat, protein and carbohydrate are alterations in the Ramadan month due to Dietary habits during Ramadan are not similar to the rest of the year (2).The nutrition in Ramadan might be an effect on multi-metabolism of the body (3), which could prompt to impact on physiology such as hematological parameters that parameters could be considered as the red blood cell parameters and the white blood cell parameters.

There is few studies evaluation of the red blood cell parameters and the white blood cell parameters during the Ramadan month $(4,5)$, while there are many studies evaluate some parameters related to red blood cell or white blood cell among the fasters in the Ramadan month (6-8) but they are controversial. The methodologies in previous studies such as big sample sizes and comparison between before and during Ramadan month, and also samples characteristics such as student, separated gender sampling, single are few. Therefore, the present study investigates the effect of Fasting during Ramadan month on red blood cell parameters and White blood cell parameters in single females' student graduate in Raparin University.

\section{METHODS}

\section{Subjects}

The target study was single females' student graduate at nursing college in Raparin University, Iraq. All of the students, they are from Rania city. Their physical Activities during the month of Ramadan were a combination of writing exam in college and study at their house. This Study was conducted in the month of Ramadan during June and July / 2016, and the average duration of fasting was around 16 hours a day. The mean climate temperature and humidity were $23^{\circ} \mathrm{C}$ and $22 \%$, and $25.5^{\circ} \mathrm{C}$ and $21 \%$ during June and July respectively. There were no special nutritional regimens and recommendations during the whole study. To maintain a sample of homogeneity, all participants were chosen from the same living community, Rania city, Iraq, student in the College of Nursing of Raprin
University, so that the socioeconomic levels were highly similar. 30 females' healthy university students with age range from 19 to 23 years who were a fast during the Ramadan month were included in the current study. The detail history about the age, gender, marital status, family history and drug history were taken from the subjects. Subjects having any acute or chronic disease such as diabetes, hypertension, metabolic disorders or any medication, also pregnancy or lactation were excluded from the study.

Blood samples were collected by venepunction from forearm vein that Blood samples were from each volunteer before three days before the beginning of the Ramadan month and 28th day of the Ramadan month at a physiology Laboratory in the nursing college of Raparin university during $4 \mathrm{pm}$. Blood sample was poured into a tube containing K2EDTA. All samples were checked for clots, hemolysis and mixed well before analysis. The evaluation of Red Blood Cel Parameters and white Blood Cell Parameters were analyzed by system SwelabAlfa automated hematology analyzer.

Ethical consideration

This review was approved by the Ethical Committee in the College of Nursing University of Raparin, Iraq.

\section{Data analysis}

Statistical Package for Social Science (SPSS) V20 was used to Statistical analysis of present study. Mean \pm Std. Error (standard Error) was expressed in this study. The comparison between mean of the group in this study was performed by paired sample T-test. A significant value was taken $\mathrm{P}<0.05$ for all results.

\section{RESULTS}

$R B C$ and its related parameters

Red blood cells (RBC) count remained no alteration in Ramadan ( $\mathrm{P}=0.095)$. Hemoglobin Hematocrit, Mean corpuscular volume (MCV), Mean corpuscular hemoglobin concentration ( $\mathrm{MCHC})$, Mean corpuscular hemoglobin concentration (MCHC), Red Density Width -coefficient of variation (RDW-CV) and Red Density Width -standard deviation (RDW-SD) were significantly increased during the Ramadan fasting period as compared to pre-Ramadan fasting period $(\mathrm{P}<0.05$, Table 1$)$

Total and differential WBC count

White Blood cells count decreased significantly in end of the Ramadan month as compared to pre-Ramadan fasting .Lymphocytes and Neutrophils percen appeared significantly elevation during the Ramadan fasting month compared with before Ramadan .Mixed white blood cells percent were no change during the Ramadan fasting month (Table 2).

Table 1. The change of RBC Parameter Before and During Ramadan

\begin{tabular}{|c|c|c|c|c|}
\hline Parameter & UNITS & $\begin{array}{l}\text { Before Ramadan } \\
\text { Mean } \pm \text { Std. Error }\end{array}$ & $\begin{array}{l}\text { During Ramadan } \\
\text { Mean } \pm \text { Std. Error }\end{array}$ & p-value \\
\hline Red blood cells count & $\left(\mathrm{X} 10^{12} / \mathrm{L}\right)$ & $4.7693 \pm 0.40964$ & $4.97 \pm 0.59629$ & 0.095 \\
\hline Hemoglobin & $(g / d l)$ & $12.9133 \pm 1.24256$ & $13.5067 \pm 1.95200$ & $0.000 * *$ \\
\hline Hematocrit & (\%) & $40.88 \pm 4.93652$ & $42.38 \pm 5.99076$ & $0.004 * *$ \\
\hline Mean corpuscular volume & (fl) & $84.58 \pm 12.70874$ & $84.7267 \pm 8.69121$ & $0.002 * *$ \\
\hline Mean corpuscular hemoglobin & (pg) & $27.23 \pm 3.05458$ & $27.3 \pm 3.0831$ & $0.000 * *$ \\
\hline $\begin{array}{l}\text { Mean corpuscular hemoglobin } \\
\text { concentration }\end{array}$ & (g/dl) & $31.4067 \pm 0.72727$ & $32.1833 \pm 0.68233$ & $0.000 * *$ \\
\hline $\begin{array}{l}\text { Red Density Width -coefficient of } \\
\text { variation }\end{array}$ & (\%) & $13.7767 \pm 1.02509$ & $14.0367 \pm 0.98803$ & $0.000 * *$ \\
\hline $\begin{array}{l}\text { Red Density Width- standard } \\
\text { deviation }\end{array}$ & (fl) & $53.6733 \pm 5.49005$ & $54.3833 \pm 6.20618$ & $0.000 * *$ \\
\hline
\end{tabular}

Values presented as mean \pm Std. Error (for single females' student graduate group, $\mathrm{n}=30$ ).Std. Error: standard Error, $* \mathrm{P}<0.05, * * \mathrm{P}<0.01$.

Table 2. The difference of WBC parameter before and During Ramadan.

\begin{tabular}{|c|c|c|c|c|}
\hline Parameter & UNITS & Before Ramadan & During Ramadan & p-value \\
\hline White Blood cells count & (X109/L) & $6.9767 \pm 1.53638$ & $6.4033 \pm 1.66826$ & $0.033^{*}$ \\
\hline Neutrophils & $(\%)$ & $34.1933 \pm 6.78360$ & $35.7267 \pm 6.92905$ & $0.039^{*}$ \\
\hline mixed white blood cells & $(\%)$ & $4.9633 \pm 2.64386$ & $3.4667 \pm 0.56161$ & 0.185 \\
\hline Lymphocyte & $(\%)$ & $60.7733 \pm 7.86147$ & $60.8067 \pm 7.10643$ & $0.042 *$ \\
\hline
\end{tabular}

Values presented as mean \pm Std. Error (for single females' student graduate group, $\mathrm{n}=30$ ).Std. Error: standard Error, $* \mathrm{P}<0.05, * * \mathrm{P}<0.01$. 


\section{DISCUSSION}

The observations of this study, the fasting during Ramadan has effecting on red blood cell parameters and also White blood cell parameters (e.g. Hb, HCT, WBC count) among study population.

The current result showed statistically no difference of red blood cell count (RBC). This regard was agreement with observations made by other authors (5, $9,10,11)$. While, other literatures reported significantly low RBC count in Ramadan (8). In another hand, the literatures noted higher RBC counts after fasting in Ramadan (12).

This result revealed hemoglobin $(\mathrm{Hb})$ and hematocrit $(\mathrm{HCT})$ increased during fasting Ramadan. Conversely, literatures noted a significant decreasing in hemoglobin and hematocrit $(8,13,14)$. While, another investigations have reported no alteration in both parameter during Ramadan $(6,11)$. Ramadan et al (9) investigated hematocrit in 15 fasters Kuwaitis male for hematocrit in Ramadan and found hematocrit remained unchanged during Ramadan. In another hand, researchers noted low hemoglobin and a high hematocrit in Ramadan (15). Bilto study showed a decrease in hematocrit and a no alteration in hemoglobin when compared the end of Ramadan fasting with pre Ramadan fasting (10). The Result of Nematy review reported no change hemoglobin level after fasting Ramadan (12)

However, Disparity of the result in red blood cell count, hemoglobin and hematocrit in previous studies may be due to dehydration temperature, weather, nutrition style, and life style during Ramadan.

In current result the Mean corpuscular volume (MCV), Mean corpuscular hemoglobin $(\mathrm{MCH})$ and Mean corpuscular hemoglobin concentration (MCHC) were statistically significant slightly increasing during Ramadan. Tawagidu study discovered increment of MCV and low MCHC in end of the Ramadan month fasting as compared with before of Ramadan (11). Also Nematy et al (12) noted significantly low MCV and MCHC after Ramadan. Another study demonstrated no change of $\mathrm{MCV}$ but $\mathrm{MCH}, \mathrm{MCHC}$ increased significantly in Ramadan (10). The alteration of $\mathrm{MCV}, \mathrm{MCH}$ and $\mathrm{MCHC}$ are depending on $\mathrm{Hb}, \mathrm{HCT}$ and $\mathrm{RBC}$ according on mathematical calculations; $\mathrm{MCV}=$ (Packed cell volume/ Red blood cells count x 10); $\mathrm{MCH}=$ (Hemoglobin / Red blood cells count) and $\mathrm{MCHC}=($ Hemoglobin $/$ Packed cell volume) (16).

Red Density Width -coefficient of variation (RDW-CV) and Red Density Width standard deviation (RDW-SD) were statistically a significant increase during Ramadan. Tayebi et al. (17) examined twenty samples in pre and post Ramadan fasting RDW-CV and found no alteration in both group. Also, Fararjeh et al.(18) noted statically no difference in RDW-CV and RDW-SD in three times Before Ramadan, During Ramadan And After Ramadan. The alteration in RDW-CV and RDW-SD depend on the size of red cell in the blood sample.

This study clarified slightly decreasing of WBC count but in normal range during Ramadan. This finding agrees with previous studies showed low leukocyte count in fasting Ramadan $(5,9)$. Conversely the previous studies found no difference in fasters in Ramadan month $(5,8,10,11,18,19,20)$. In another hand, studies revealed higher WBC counts in Ramadan fasting $(12,21)$. In this result Neutrophils and Lymphocyte percent were slightly higher in end of Ramadan fasting as compared with before Ramadan. This finding of Neutrophils count was Inconsistent with previous studies, that studies did not observe any change in the neutrophil of subjects during Ramadan month $(18,20,22,23)$. The result Lymphocytes were very much similar to observations made by other researchers $(20,22,23)$. While, another study found no change in Lymphocytes among the healthy faster in Ramadan (18). MXD was no difference in Ramadan compared with before Ramadan. Study was found to evaluate the change in lymphocytes during.

This study required further studies to understand the mechanisms the alteration of red blood cell parameters and white blood cell parameters in the Ramadan fasting month.

\section{Conflict of interest}

No conflict of interest was declared by the authors.

\section{REFERENCES}

1. El Ati J, Beji C, Danguir F. Increased Fat Oxidation During Ramadan Fasting in Healthy Women: An Adaptative Mechanism For Body Weight Maintenance. Am J Clin Nutri 1995;62:302-7

2. Gumaa K, Mustafa K, Mahmoud N, Gader A. The effects of fasting in Ramadan. I. Serum uric acid and lipid concentrations. Br J Nutr 1978; 40:573-81.
3. Ziaee V, Razaei M, Ahmadinejad Z, Shaikh H, Yousefi R, Yarmohammadi L, Bozorgi F, Behjati MJ. The changes of metabolic profile and weight during Ramadan fasting. Singapore Med J 2006;47:409-14

4. Unalacak M, Kara IH, Baltaci D, Erdem O, Bucaktepe PG .Effects of Ramadan Fasting on Biochemical and Hematological Parameters and Cytokines in Healthy and Obese Individuals. Metab Syndr Relat Disord 2011;9:156-61

5. Sarraf-Zadegan N, Atashi M, Naderi GA, Baghai AM, Asgary S, Fatehifar MR, Samarian $\mathrm{H}$, Zarei M. The Effect of Fasting in Ramadan on the Values and Interrelations between Biochemical, Coagulation and Hematological Factors. Ann Saudi Med 2000; 20: 377-81

6. Azizi F. Research in Islamic fasting and health. Ann Saudi Med.22: 186-91, 2002.

7. Bouhlel E, Salhi Z, Bouhlel H, Mdella S, Amamou A, Zaouali M, Mercier J, Bigard X, Tabka Z, Zbidi A, Shephard RJ. Effect of Ramadan fasting on fue oxidation during exercise in trained male rugby players. Diabetes Metab 2006;32:617-24

8. Attarzadeh Hosseini SR, Hejazi K, Nikroo H. The Effects of Ramadan Fasting and Physical Activity on Blood Hematological-Biochemical Parameters. Iran J Basic Med Sci 2013;16:845-9

9. Ramadan J, Mousa M, Telahoun G. Effect of Ramadan Fasting on Physical Performance, Blood and Body Composition. Med Princ Pract 1995;4:20412

10. Bilto Y. Effects of Ramadan fasting on body weight and the biochemical and haematological parameters of the blood. ARAB GULF J SCI RES 1998;16:1-13

11. Tawagidu M. The effect of Ramadan fasting on body anthropometric measurements, hematological indices and serum lipid profile in Ghanaians. PhD thesis. University of Ghana, 2016.

12. Nematy $M$, Alinezhad-Namaghi $M$, Rashed MM, Mozhdehifard $M$, Sajjadi SS, Akhlaghi S, Sabery M, Mohajeri SA, Shalaey N, Moohebati M, Norouzy A. Effects of Ramadan fasting on cardiovascular risk factors: a prospective observational study. Nutr J 2012;10:11-69

13. Dewanti L, Watanabe $C$, Sulistiawati E Ohtsuka R. Unexpected changes in blood pressure and haematological parameters among fasting and nonfasting workers during Ramadan in Indoensia. Eur J Clin Nutr 2006;60: 877-81

14. Maughan R, Leiper J, Bartagi Z. Effect of Ramadan fasting on some biochemical and haematological parameters in Tunisian youth soccer players undertaking their usual training and competition schedule. J Sports Sci 2008;26:39-46

15. Chaouachi A, Chamari K, Roky R . Lipid profiles of judo athletes during Ramadan. Int J Sports Med 2008;29:282-8

16. Asif $M$, Karim S, Umar Z,Malik A, Ismail T,Chaudhary $A$,Hussain Alqahtani $M$, Rasool $M$. Effect of cigarette smoking based on hematological parameters: comparison between male smokers and nonsmokers. Turk J Biochem 2013;38:75-80

17. Tayebi SM, Hanachi P, Ghanbari NA, Ali PN, Ghorban Alizadeh Ghaziani F. Ramadan Fasting and Weight-Lifting Training on Vascular Volumes and Hematological Profiles in Young Male Weight-Lifters. Global Journal of Health Science 2010;2:160-6

18. Fararjeh M, AlJamal A, Faris MAl, Al-Kurd R, Khalil M, Al-Bustanji Y. Effect of intermittent fasting on lipid profile and hematological parameters in healthy volunteers in Jordan . Univers J Med Dent 2012;1: 5-9

19. Chaouachi A, Coutts AJ, Wong DP, Roky R, Mbazaa A, Amri M ,Chamari K . Haematological, inflammatory, and immunological responses in elite judo athletes maintaining high training loads during Ramadan. APPL PHYSIOL NUTR ME 2009;34: 907-15

20. Oukal M. Effect of Ramadan Fasting on Anthropometric Measurements and some Biochemical Parameters among Overweight Male Adults in Rafah City. Master thesis. Al-Azhar University-Gaza, 2010.

21. Attarzadeh Hosseini SR, Motahari Rad M, Hejazi K. The Effects of Ramadan Fasting and Physical Activity on Body Composition and HematologicalBiochemical Parameters. J Fasting Health 2014; 2: 96-103

22. Askari V, Alavinezhad A, Boskabady M. The impact of "Ramadan fasting period" on total and differential white blood cells, haematological indices, inflammatory biomarker, respiratory symptoms and pulmonary function tests of healthy and asthmatic patients. Allergol Immunopathol (Madr). 2016; 44:359-67.

23. Furuncuoglu, Y., Karaca, E., Aras, S. and Yönem A . Metabolic, Biochemical and Psychiatric Alterations in Healthy Subjects during Ramadan. Pakistan Journal of Nutrition, 2007 6: 209-11. 